\title{
The Concept of Indian Aesthetic in the Poetry of William Wordsworth.
}

\author{
Dr. Jai Shankar Tiwari* \\ Assistant Professor, Department of English Nehru Gram Bharati (Deemed to Be) University. Kotwa Jamunipur \\ Campus, Prayagraj-221505, UP, India
}

*Corresponding Authors: Dr. Jai Shankar Tiwari, Assistant Professor, Department of English Nehru Gram Bharati (Deemed to Be) Universitv. Kotwa Jamunipur Campus. Pravagrai-221505. UP. India

Abstract: Thus harmony and suggestion which reveal the poets imagination finds its true appreciation in the readers heart.

Glory to that true nature of the muse named the poet and the reader. After a careful and deep study of Indian poetics right from Bharat Muni to Abhinavgupta and Mammat and the works of William Wordsworth, I come to a conclusion that Wordsworth's poetry becomes greatly enjoyable if read in this light. World worth has a wide appeal primarily because the experiences which form the bedrock of his poetry are all deeply human and the emotions which they arouse are primary human emotions which human beings of all ages can share. At the same time there is an inspired poetic contemplation of a vision, the revelations of the mysteries of life from a deep emotional absorption in the central peace at the core of the universe and the establishment of a complex relationship between the natural world and the mind of man.

Wordsworth's exalted state of mind and philosophy tempted me to examine the currents and undercurrents in Indian and English literary tradition, minutely. With simple yet graceful poetic sweetness, nobility and dignity Wordsworth has established a tradition in his own right and sits at one of the loftiest peaks of the literary mountain.

William Wordsworth as a poet of nature had interest me since my undergraduate days. A further appreciation took hold of me as I read his serious works, critical works, and vast critical literature on his works by eminent authors. About the same time I became interested in the Indian Aesthetic Tradition in literature. This interest finally led me to make a juxtaposed study of the great English poet and great Indian poetry.

While tracing the history of Indian and English poetic Tradition which forms the subject matter of my interest, I have analysed in detail the poetic excellences enumerated by great Indian critics which include various embellishments of speech and literary genres. The literary thrusts in course of poetic writings as Abhidha, Lakshana, Vyanjana, Tatparya, Dhvani, Vakrokti and Aucitya have been clearly explained with befitting examples as well as my ability permitted.

Abhidha is the realistic description sans roundabout suggestions. However, some critics say that the meaning of a sentence is something over and above the meaning of its constituent, words and expressions. The totality of effect exeeds the meaning of the words. They call it Tatparya or Import of the power of syntax. Laksana indicates a meaning allied with the lteral meaning of the word resolving contradiction if any in the relation between the literal meaning of several words. The phrase 'law and impulse' in Wordsworth's Three Years She Grew' may be taken as an illustration. The two words do not go together, hence Laksana here comes in force to clarify the meaning.

Poetic language with its beauty and effectiveness has been a point of much discussion among Indian scholars. Krishnamoorty states that the whole field of Sanskrit Alankara Sastra or poetics may be regarded as one continued attempt to unravel the mystery of beauty in poetic language. As far as beauty and language are concerned, it should be mentioned that Wordsworth made use of Svabhavokti (spontaneous self- expression) in a major portion of his work. But poetry apart from providing pleasure to the reader served other purposes too. It was its requirement to be simple and natural as far 
as possible Hindu philosophers planned their whole individual life for the attainment of the fullest development of personality, and utilized literature as a means for achieving the great ends of life. They realized that on the one hand, if a poet must $n$ ecessarily start from the level of the individual in order to lead him to the heights he is capable of reaching, it becomes imperative on the other hand that, the poet should realize his task as a social reformer. The knowledge, for which of metaphysical epistemological and ethical standard is necessary. This realization came to Wordsworth before he started writing poetry, and hence on this basis it can be said with reasonable emphasis that he had the conscious or unconscious knowledge regarding Indian tradition. Messeges that Wordsworth tried to convey to his readers were mainly through nature. The new Romantic note struck in the Lyrical Ballads (published 1798) was the glorification of the common man and the declaration of the divinity of nature. This emphasis on the divinity of nature secures of him a sound 'niche' connecting him to the Indian Aesthetic Tradition. Wordsworth believed that for his moral re-habilitation and mental peace man needs to establish contact of life with the beauties of Nature such as lie embedded in her flowers and trees, mountains and lakes, rivers and cataracts, rills and brooks, cascades and clouds vegetation and foliage. This enthusiasm for nature has been mainstay of Indian classical poetry. Wordsworth's aesthetic spirit revolted in the face of materialism, 'Dear God, I'd rather be a pagan suckled in a creed outworn.'

Wordsworth realized that beyond the limits of material existence was a wider life animating the entire universe and there must take place a synthesis and integration of the individual soul with the universal soul. His poetry was an expression of the joy and glory of this metaphysical realization. His relation to nature was one of the child to his mother. As a poet therefore, he came nearer to the attitude of the Orient. Wordsworth's 'mighty world of the eye and ear' suts him by the side of the ancient Indian poets whose aesthetic sensibilities were akin to his. His pantheism echoes what the Chandogya Upanishad says that there is a spiritual principle called Brahma which, creates the universe, pervades the universe and is the universe. The greatness of Wordsworth lies in being the eponent of this kind of mysticism in a simple and direct manner to the west and my study on Wordsworth and the Indian Aesthetics deals with this spiritual relationship. The means to attain this state of sublime bliss is through Nature. He says:

And I have felt a presence that disturbs me with the joy

Of elevated thoughts, a sense sublime

Of something far more deeply interfused

Whose dwelling is the light of the setting sun

And the round ocean and the living air,

And the blue sky and in the mind of man,

A motion and a spirit that impels

All thinking things, all objects of all thought

And rolls through all things.

The spontaneity of expression with a deep rooted philosophy was the remarkable feature of Wordsworth's poetry. Harold Bloom calls it 'Aesthetic Contemplation'. Camatkar, asvada and ananda to be transformed into poetry required divine inspiration and was ardently sought after Indian poets. The poetry of Wordsworth has traces of Trika Philosophy based on metaphysical ideal, truth of spiritual existence, self-sufficiency of the pure spirit and the experience of the eternal "I AM THIS', which is pure in nature. Abhivagupta, an Ancient Indian celebrity propounds that at this stage everything appears an aspect of one's own self. He realizes that nothing else exists; he alone exists in manifold forms.

In Wordsworth's poetry we find the realization of this experience:

The blessed mood

In which the burthen of the mystery

In which the heavy and the weary weight 
Of all this unintelligible world

Is lightened - that serene and blessed mood,

In which the affections gently lead us on

Until, the breath of this corporeal frame

And even the motions of our human blood

Almost suspended, we are laid asleep

In body and become a living soul.

The study of Wordsworth's poetry and the Indian theory Of Dhvani forms the basis, Wordsworth's highly suggestive and reflective poetry have been categorized under divisions and sub-divisions of Dhvani made by Anandvardhan, a great Indian thinker on poetic art and criticism. Rasa, that is aesthetic emotion, is the soul of poetry. Auchitya (propriety) is the mode by which the body of poetry reveals and conveys true and superceding joy within proper limits. Together, Rasa, Dhvani and Auchitya form the essence of poetry. Traditionally the function of poetry was supposed to instruct and delight but for Wordsworth, the function of poetry is to give pleasure, of a serious and a more exalted kind. It is the pleasure which results from increased knowledge and understanding. The beautiful and the wonderful, the sweet and the sublime, the divine and the graceful are crystallized for this purpose. The suggestions emerge out of a brooding mind alive to the fortifying power of Nature. Irony, satire, harshness, fury and anger are but rarely found in his abundant writings. Rasa is considered to be 'the sol of a poem, the source of its birth and its organic growth: The kind of poetry which is suggestive is Dhvani, 'yatrathah sabdo va tamanthamupasarjanikritasvarthau vyanktah kavya-viseshah sa dhvaniriti suribhih kathitah'.

The kind of poetry in which the denoted meaning or the denoted word makes itself subservient and reveals the suggested sense is called Dhvani by scholars.

The suggestive word, the suggestive meaning, the relation of suggestion, the suggested meaning and the poem with such words and meaning are the five parameters on which the Dhvani in poetry should be understood.

Together these may form, as Coleridge says in the Biographia Literaria 'one graceful and intelligent whole'. The most important and broad division are known as Vastu-Dhvani, Alankara-Dhvani and Rasa-Dhvani. What the great ancient scholars Anandvardhan and Abhinavgupta emphasize is that poetry in its essence is this apex of emotional experience and even the lowest stage of enjoying a figure of speech cannot be possible without the suggestions of the essence. Just as a body bereft of its soul cannot be made attractive by ornaments, so a poem bereft of Rasa cannot be beautified by a figure of speech. Rasa or Dhvani should not be made a conflicting principle for dissection of poetry, for a poem without the swetness of the Rasa experience is deficient and unimpressive. It is in this light that I have analysed as best as I could Wordsworth's poetry.

The concept of Auchitya that is propriety in Indian Aesthetic Tradition was to ennoble the human mind and foster a civilized, cultured and peaceful existence. The purpose of literary writings was to reveal through examples the advantages of a morally exalted existence. The discipline of thought, word and action was advocated for a life full of happiness, peaceful death and freedom from the cycle of birth and rebirth. Wordsworth's poetry sprang from the very core of his heart. Set rules do not suppress the flow of powerful emotions in him. His poetry is deeply and pervasively personal yet it never oversteps the boundaries of propriety. It was because he was a conscious artist and although he advocated spontaneous expression of feelings, he set rules voluntarily for himself. He restrained himself from expressing the impulse of the moment and has often been criticized for this. It is for this reason, though a highly subjective, personal poet he can be ranked with the poets of Ancient Indian Tradition who rigidly followed the set rules of propriety. With Wordsworth, Propriety was a part of his being, and thus from the Indian point of view his poetry is considered to be of a very exalted type. As Dhvanikara says, 'anaucityadrite nanyadrasabhangasya karanam prasiddhaucityabandhastu rasasyapanishat para' meaning that there is no other cause for a breach of Rasa except impropriety. The great secret of Rasa is to be in consonance with the well known idea of propriety. 
Auchitya (Propriety) may be considered at various levels, namely at the level of subjectivity, in the form and content of poetry, in the concept of poetic justice, suggestiveness and the mode of expression. At the level of subjectivity, Sanskrit literature enunciates a concept of Purusartha that is, the proper development of a personality which leads to magnify all that is fine in a human being by not avoiding any of his natural tendencies. Propreity is essential because it reduces wasteful and destructive efforts which is a common tendency and instead of curbing a tendency, develops it through proper channels. The tale of 'Peter Bell' shows the kind of role poetry can play in the betterment of society. According to the rules of propriety one of the aims of poetry is to improve the life of the common man to show what to do and what not to do , and to help men achieve the goals of life not by common persuasion or resorting to undesirable action, but by a change in the very attitude of mind. Thus literature becomes a means of moral culture, giving proper guidance to individual and the society, for these are universally accepted facts. In the prologue to 'Peter Bell' Wordsworth says:

There was a time when all mankind

Did Listen with faith sincere;

To tuneful tongues in mystery versed

Then poets fearlessly rehearsed

The wonders of a wild career

In the writing of poetry, propriety may be likened to the performance of an orchestra. The note of all the singers and the Instruments give out a diversely unified musical Rasa. In poetry, letters, words, sentences, themes, combination of characters and arrangements of figures of speech harmonize to create a unified piece with all the Rasa's intact. Therefore, the study of propriety is based on the assumption that if Rasa was the life of poetry, propriety became the life of Rasa.

\section{WORKS CITED}

Abrahams, M.H: The English Romantic Poets. (New York, Paper back, 1960)

Beach, Joseph Warren: the concept of Nature in Nineteen century English poetry (New York, 1956)

Gill, Stephen: William words worth 'A life, Oxford University press, 1990)

Gravil, Richard: William Wordsworth, 'Lyrically Ballads’ Humanities- Ebooks 2008

Hutchinson, Thomas: Wordsworth's political works, Oxford university press. 1910

Jacobus, Mary: Tradition and Experiment in the Lyrical Ballads, 1798, London Clarendon Press, 1976.

MC Master, Graham: William Wordsworth, ‘A critical Anthology, Penguin. 1972.

Citation: Dr. Jai Shankar Tiwari. "The Concept of Indian Aesthetic in the Poetry of William Wordsworth" International Journal on Studies in English Language and Literature (IJSELL), vol 8, no.43, 2020, pp. 11-14. doi: http://dx.doi.org/10.20431/2347-3134.0804002.

Copyright: (C) 2020 Authors. This is an open-access article distributed under the terms of the Creative Commons Attribution License, which permits unrestricted use, distribution, and reproduction in any medium, provided the original author and source are credited. 